\title{
Scaling Up Housing First Pilots - Drivers and Barriers $^{1}$
}

\author{
Marcus Knutagård* \\ School of Social Work \\ Lund University \\ Email: marcus.knutagard@soch.lu.se
}

\author{
Arne Kristiansen \\ School of Social Work \\ Lund University \\ Email: arne.kristiansen@soch.lu.se
}

${ }^{*}$ corresponding author

\begin{abstract}
There has been an increased interest in Housing First services in Sweden over the past few years. The model was first developed in New York by the organization Pathways to Housing. The growing interest in Housing First as a response to ending long-term homelessness is seen not only in the US and Canada, but also in Europe. One reason for this is the mass of evidence showing high housing retention rates with Housing First services as compared with traditional services. This article aims to analyse the drivers and barriers that hinder or facilitate the scaling up of Housing First pilots. The research question is: Is it possible to incorporate lessons learned from the Housing First pilot into the existing system of homelessness services? In other words: Is it possible to put new wine into old bottles?
\end{abstract}

\footnotetext{
1 Knutagård \& Kristiansen (2016). Scaling Up Housing First Pilots - Drivers and Barriers. Paper presented at the Third ISA Forum of Sociology, The Futures We Want: Global Sociology and the Struggles for a Better World, Vienna, Austria, July 10-14, 2016. An oral presentation with the same title was given in Warsaw in September 2014 at the 9th European Research Conference: Homelessness in Times of Crisis.
} 
This is an ongoing research project on Housing First services in Sweden, with the specific focus on the Housing First pilot in the city of Helsingborg. The empirical material consists of in-depth interviews and focus group interviews with project managers, support workers and other stakeholders. The main results show that leadership is essential and a key driver for the scaling-up process. Another driver is the importance of repeating the vision and goals of the idea to keep the story alive. A third key driver is that the staff has identified the Housing First approach as a relative advantage and believes in the idea. The main barrier to the scaling-up process lies in the structures that maintain and surround the social housing programme.

Keywords: Housing First, Scaling Up, Social Innovation, Homelessness, Institutional Change, Drivers and Barriers

\section{Introduction}

Social innovations are often called upon as a solutions to the current challenges that humanity is facing: poverty, ageing populations and climate change. Since the financial crisis of 2008, we have seen severe reductions in the provision of welfare services and a growing number of people who have been affected by evictions from their homes. Some European countries have been more affected than others (Rønning \& Knutagård, 2015; Martinelli, 2012). The fragility of European social cohesion became even more evident on the 23 June 2016, when the UK voted on leaving the European Union after a referendum was held. In this context, one can be critical towards the fact that social innovations are called upon in order to confront the challenges that we are facing. The dilemma is that social innovations are seen as a substitute for a retrenching public welfare rather than as a complement (Brandsen et al., 2016a). How can small-scale innovations end homelessness? Aren't radical innovations what we need in order to transform existing institutions and create systemic change? In this article, we will take a closer look at how a social innovation, which has been implemented in a local welfare system, is being scaled up in order to tackle a persistent social problem: homelessness. ${ }^{2}$ The social phenomenon of homelessness is a relevant area of study, since it involves a specific group of the population that can be seen as one of the most excluded (Arnold, 2004). A quick clarification on the contextual settings is that, even though Sweden has a history of large-scale housing interventions, such as the Million Homes

\footnotetext{
2 The project was funded by Plattformen, Helsingborg City, during the period of 20142016.
} 
Programme, the responsibility for the housing provision lies at the municipal level. At the time of this writing, a majority (240) of the 290 municipalities in Sweden have a housing shortage and a diminishing rental market, especially public housing provided by the municipal housing companies $(94 \%$ of the population live in a municipality with a housing shortage). Since the beginning of the 1990's, the national housing policy has witnessed a system shift, where several of the former housing institutions have been abolished (Ministry of Housing) (Lindbom, 2001; Sahlin, 2015). The Swedish housing market is currently described as one of the most deregulated markets in the Western world (Lind \& Lundström, 2007). Since the responsibility of the housing provision is decentralised, it is of even greater importance to focus on the local level in the analysis of how policies on the national level play out (cf. Kazepov, 2010). In relation to homelessness, the urban context or the specific conditions in a city might be more relevant than the policies on the national level (Brandsen et al., 2016a, p. 7).

The aim of this paper is to analyse the drivers that facilitate and barriers that hinder the scale-up of Housing First pilots. The case in Helsingborg is about trying to scale up Housing First within the existing social housing programme in the city. We ask if it is possible to incorporate lessons learned from the Housing First pilot into the existing system of homelessness services. In other words: is it possible to put new wine into old bottles?

\section{Background}

Housing First began as a programme in New York in 1992. The programme was invented by Sam Tsemberis, the founder of the Pathways to Housing, as a response to the mainstream approach to homeless services, the so-called 'staircase model' or 'continuum of care'. In the staircase model, clients have to prove that they are housing ready in order to move on to the next step. As part of this, abstinence from drug and alcohol use is a prerequisite, and the clients are expected to first accept treatment in order to ultimately obtain an independent apartment. For many, the staircase model has led to a feeling of uncertainty, not knowing for how long to stay or what to do in order to progress to the next step. It has often proven to be too difficult to climb all the steps, and many give up trying after failing to comply with all the rules (Padgett et al., 2016). Even the social workers have said that they do not want to place a homeless person in an independent apartment because they do not want to make them fail again. The demands are high, but the expectations are low (Knutagård, 2009). Independent housing can be seen as a goal in the staircase model. In 
the Housing First model, housing is a means; it is a precondition in order to be able to deal with other life challenges. This discrepancy between the two different models shows that they are based on two totally different logics.

In Housing First, housing is seen as a basic human right. This shows the importance of housing and the broader idea of the meaning of housing. Having your own house is more than a roof over your head and walls around you. The meaning of housing can be connected to the concept of ontological security (Padgett, 2007). This is a sense of stability and safety in which daily routines can be performed. Having your own home makes it possible for an individual to be free from surveillance and to have control over his or her own front door. Having your own home also makes it possible to construct identities (Dupuis \& Thorns, 1998, p. 29).

Housing First has been described as an innovation (Felton, 2003; Rønning et al., 2013; Knutagård, 2015; Pleace, 2016). It has even been seen as resulting in a paradigm shift (Padgett et al., 2016). In the recent literature, the model is seen as an innovation since it combines three central components: (1) consumer choice, (2) community-based, mobile support services, and (3) permanent scatter-site housing, that on their own have been considered innovative (Padgett et al., 2016, p. 3). These three components are merged together with a fourth component, harm reduction, making the new combination an innovative practice. ${ }^{3}$

Housing First is a model where homeless people are given an independent apartment in which the individual has the control over their own entry door. But, Housing First is not only housing, it is an approach based on a philosophy around the importance of relationship building, empathy, service-user participation, etc. It is important to note that the scaling-up project in Helsingborg is not primarily about arranging more Housing First apartments; it is the ambition to transform an authoritarian and repressive approach into a more humane, empathetic, relationship building approach.

Housing First, as an innovative practice, was first introduced to and then diffused through Sweden at the end of 2009. Stockholm and Helsingborg were the first two municipalities to offer Housing First services. In 2010, the first tenants moved in (Knutagård \& Kristiansen, 2013). Since then, another 13

\footnotetext{
${ }^{3}$ In the description of the philosophy behind the original model, eight core principles are identified: (1) housing as a basic human right, (2) respect, warmth, and compassion for all clients, (3) a commitment to working with clients for as long as they need, (4) scattered-site housing, independent apartments, (5) separation of housing and services, (6) consumer choice and self-determination, (7) a recovery orientation and (8) harm reduction (Tsemberis, 2015, p. 18).
} 
municipalities have started their own Housing First services (Knutagård, 2015). They began as small-scale pilots with 1-10 apartments, and over time, the number of flats has increased. In some municipalities, it has been more difficult than in others to acquire more apartments over time. The Housing First services that have developed in Sweden all differ, and they are all examples of how innovations are being translated into local contexts by change agents (institutional entrepreneurs) who receive or introduce the innovation in a new setting (Hardy \& Maguire, 2008). Although they differ in many respects, they do share commonalities and some core components (Knutagård \& Kristiansen, 2013). Interestingly, the Housing First services all evidence great results in the housing stability and housing retention rates. The scaling-up process in a Swedish context can be seen rather as a 'scaling-out' process where many Housing First pilots emerge in different locations but in, more or less, the same size (Iriss, 2016).

In this article, we will focus on the Housing First service in the city of Helsingborg. We will, more specifically, focus on how the results from the evaluation of the Housing First service is scaled up into the municipality's social housing system (Kristiansen \& Espmarker, 2012; Kristiansen, 2013; Knutagård \& Kristiansen, 2013). The evaluation showed that the Housing First service in Helsingborg worked well, with an almost $90 \%$ housing retention rate after a three-year period. From the time the first tenant moved in in September 2010 until the end of the project in May 2013, 19 persons had been part of the project, and only three persons had lost their apartments. ${ }^{4}$ During the same year (2013), the city added 30 new apartments to the Social Housing Programme. In 2013, 25 apartments in the social housing programme were evicted due to arrears of rent or because of disturbances, etc. This major difference between the success of the Housing First project and the failure of the existing social housing programme led to making the Housing First project a permanent service in the city and generating support for scaling up the Housing First project. The latter meant that the lessons learnt from the Housing First pilot should be implemented in the entire social housing programme in the city.

\footnotetext{
${ }^{4}$ In 2016, 49 people received housing through the Housing First service in Helsingborg since the start of 2010 . Six have been evicted, resulting in a housing retention rate of nearly $90 \%$.
} 


\begin{tabular}{|lc|}
\hline Type of housing & $\begin{array}{c}\text { Number } \\
\text { of places }\end{array}$ \\
\hline Fenix (emergency housing) & 37 \\
Kronan (low threshold housing) & 17 \\
Carnot (transitional housing) & 32 \\
Training flats & 95 \\
Social housing apartments & 162 \\
Housing First apartments & 32 \\
\hline Total & 375 \\
\hline
\end{tabular}

Table 1. Type of housing and number of places in the social housing programme in the municipality of Helsingborg in 2016.

The evaluation of the project also showed that the tenants' quality of life had improved in several ways (Kristiansen, 2013). Even though the target group for the project was open to all four homelessness situations, according to the national definition of homelessness, most of the clients came directly from the streets, night shelters or other forms of acute housing. ${ }^{5}$ The pilot also targeted those who had both serious drug use and mental health problems.

\section{Theoretical framework}

\section{Social Innovation}

As previously mentioned, Housing First has been described as a social innovation, but what exactly does that mean? Social innovation is very much a contested concept (Rønning \& Knutagård, 2015). Nevertheless, it is a widely popular one and a buzzword of our time. For many, the concept of innovation is a positive notion implying something new, most often a new technological device or a promising cure for the modern plagues that haunt mankind. The concept of social innovation is often presented as a new idea, even more recent than technological innovation. Godin (2012) argues, however, that the concept of social innovation is much older, at least 200 years old. According to Godin, social innovation was initially associated with socialism and had pejorative connotations. After the French Revolution, the concept gradually became something positive. The second phase was ascribed to social reforms, and the

\footnotetext{
5 1. Acute homelessness. 2. Institutional care and category housing. 3. Long-term housing solutions (e.g. the secondary housing market). 4. Short-term insecure housing solutions (NBHW, 2017).
} 
third phase is the one we are experiencing today, when the concept has reemerged as 'alternatives to "established" solutions to social problems or needs' (Godin, 2012, p. 6). Many attempts have been made to define social innovation. We will not attempt to present them all here, but let us consider three different definitions that exemplify the wide range of how the concept can be interpreted:

A novel solution to a social problem that is more effective, efficient, sustainable, or just than existing solutions and for which the value created accrues primarily to society as a whole rather than private individuals. (Phills et al., 2008, p. 36)

[. . .] fostering inclusion and wellbeing through improving social relations and empowerment processes: imagining and pursuing a world, a nation, a region, a locality, a community that would grant universal rights and be more socially inclusive. (Moulaert et al., 2013, p. 16)

[...] social innovations are those that, created mainly by networks and joint action in social realms beyond business and government routines, at any given moment, raise the hope and expectations of progress towards something 'better' (a more socially sustainable/democratic/effective society). (Brandsen et al., 2016a, pp. 6-7)

From the above definitions, we get a glimpse that some definitions are narrower while others are wider, inclusive and encompass almost everything. Some definitions are more management-based and related to market-oriented rhetoric and neoliberal ideals of cost-effectiveness (Klein, 2013). Others are grounded in bottom-up, grassroots-oriented or community-based action for change. We can also make a distinction between definitions that allow for incremental change and definitions that, more or less, demand radical innovations that lead to systemic change (Rønning \& Knutagård, 2015).

Our interest in social innovations lies within the field of welfare innovation. There is often a distinction between innovative private services and conventional services provided by bureaucratic public institutions. We argue, however, that the public sector has been significant in making innovations happen and making it possible for them to grow. It seems as if the divide between the private and public is outdated (cf. Mazzucato, 2013). The civil society must be brought in and involve the people affected by the services provided. Johnson (2010) elucidates the importance of open networks for creating innovations. He illustrates this with a model based on four quadrants (see Fig. 1). Johnson asks the question 'Which quadrant has the most impressive track record for generating good ideas?' (p. 220). His answer is the so-called fourth quadrant: non-market/networked. The fourth quadrant consists of networks that do their work outside the market. The non-market component is crucial for creating fertile soil for innovations to grow. 'When you introduce financial rewards into a 
system, barricades and secrecy emerge, making it harder for the open patterns of innovation to work their magic' (p. 233). Johnson's four different quadrants (pp. 219-221) represent four distinct environments where 'good ideas' can grow.

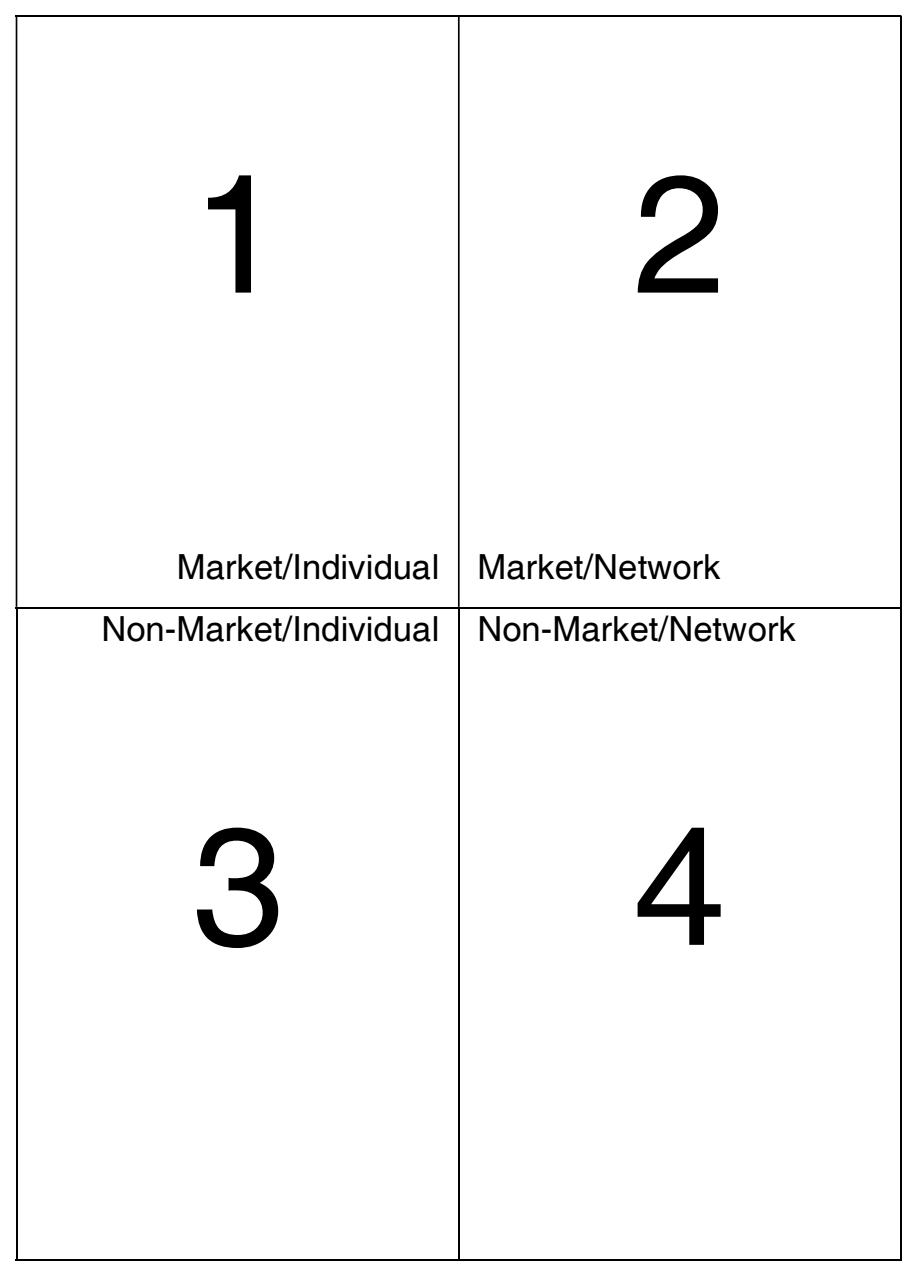

Fig. 1. The Fourth Quadrant from Johnson (2010, p. 219).

The idea behind Johnson's model is that he has plotted out around 200 innovations since Gutenberg's press. The first division that he makes is between individual inventors (Individual) and groups (Network) that collectively create innovations. The second distinction is made between those who planned to capitalize on their invention (Market) and those who see their ideas as free to connect and build upon (Non-market). Sorting the different types of innovations in this way, Johnson cites Gutenberg as a representative of the first quadrant (market-based individual). In the second, he plots the vacuum tube (networked, market). In the third quadrant, we find the World Wide Web (individual, nonmarket). Finally, in the fourth quadrant, we find the Internet (networked, nonmarket). Johnson's view is interesting in comparison to Mazzucato's (2013) 
argument that the State has been invaluable as a support and investment structure for innovations such as the Internet. Despite the lack of financial incentives, the fourth quadrant seems to be the place where innovations grow (Johnson, 210, p. 231).

\section{Scaling-up}

When the process of social innovation is described, the end goal is often that the innovation should become a mainstream practice and, in this way, replace the old approach. Milat has defined the 'scaling' as:

The ability of a health intervention shown to be efficacious on a small scale and or under controlled conditions to be expanded under real world conditions to reach a greater proportion of the eligible population, while retaining effectiveness. (2012, p. 5)

In this article, we can replace a health intervention in the quote above with a social innovation, or more specifically, the Housing First approach. From this perspective, the innovation needs to reach more people at the same time while being as effective as when it was delivered as a pilot. Unfortunately, there is not a lot of research on social innovations that have been scaled up, especially not in the field of social work. Fortunately, there is some evidence from other fields on the factors that enable or hinder the scaling-up process (Greenhalgh et al., 2012; What Works Scotland Evidence Review, 2015). The challenge with the idea of making social innovations sustainable and replacing old systems with something new is that they, in turn, will sooner or later become obsolete, and 'the longer an innovation is sustained, the less likely the organization will be open to additional innovations' (Greenhalgh et al., 2004, p. 582). Social innovations are complex processes where something new is needed, but the end result should not be too fixed. In a European context, it is clear that evidence-based social innovations that can direct social policy are sought after. Not only should they be evidence-based, they should also be 'scalable'. Contextual factors and the challenge of translating innovations from one setting to another make this idea problematic if one hopes to know that the innovation can be scaled up. Brandsen et al. (2016a) states that 'one cannot clearly predict what comes out of even a very promising innovation in the course of its development' (p. 5).

In our article, we connect the scale-up of social innovations with Rogers's (2003) theory of the diffusion of innovations. Rogers argues that five attributes play a crucial role in the rate of adoption of an innovation. These five attributes are relative advantage, compatibility, complexity, trialability and observability ( $p$. 
221). Relative advantage means that the adopters perceive the new innovation as better than the existing way of working. This also means that it is beneficial if the users of the innovation are involved in the process of developing the idea and the adaptation of the idea to a local context. The second attribute, compatibility, refers to how well the innovation is compatible with the adopters' values, needs and experiences. The third attribute is complexity. The possibility for an innovation to diffuse and be scaled up relates to how easy it is to understand its use. The more complex, the harder it is to adopt. The fourth attribute is trialability, and it is easier to scale up an innovation that is easy to test or try out. If there are too many steps and organizational changes involved to be able to try out an innovation, then it is less likely to be adopted. The final attribute is observability. If it is easy for others to observe the results of the innovation, then it is more likely to be adopted. The scaling-up process is complicated, especially if we want to see a social innovation not only as a smallscale pilot, but also as an innovation that leads to systemic or institutional change (Streeck \& Thelen, 2005).

\section{Research design and methodology}

The project started at the beginning of 2015. The idea was to try and capture the possible changes or shifts in mindset among the social workers within the Helsingborg social housing programme. This research project is connected to a comparative project where we compare the spread and growth of the different Housing First pilots in Sweden. The research design of the scaling-up project is based on a mixed-method case study design (George \& Bennett, 2005). The project consists of three different sub-studies. The empirical material that we have used for this paper comes primarily from the second study. The second sub-study consists of interviews with key stakeholders from the social services, housing companies and politicians (31 interviews in total). We have also interviewed managers, social workers, frontline staff and service users. The interviews were done shortly after the scaling-up project had started and all the staff had heard the 'innovation narrative' about the project (cf. What Works Scotland Evidence Review, 2015). At that stage, we also made site visits to all the different housing alternatives. The interviews focused on what the respondent identified as enabling or hindering factors when it came to implementing results from the Housing First pilot into their own organisation. We conducted three focus groups and made a new set of site visits. The theme of the focus groups was how the support to homeless clients had changed since the project started in early 2015 (cf. Wibeck, 2010). The first focus group consisted of all the managers at the different housing alternatives in 
Helsingborg. The other two focus groups had one representative support worker from all the different housing alternatives.

In the first sub-study, we sent a questionnaire to all the support workers in the social housing programme in Helsingborg. We also used some answers from this questionnaire related to the social workers' views of Housing First. The questionnaire was sent out to the respondents before they had received their training in motivational interviewing (MI) in January 2015 (Miller \& Rollnick, 2013). Ml is a conversational method commonly used in Housing First programmes. The method aims to strengthen the users' motivation based on their own terms. $\mathrm{Ml}$ is also used to identify so-called 'change talk'. In MI, ambivalence is highlighted as a major obstacle, as it is seen to lead to a relapse in drug abuse. The idea of this Ml training was to give the staff the same kind of 'language' to use in their contact with the homeless clients. One part of the questionnaire consists of an Interpersonal Reactivity Index (IRI; Davis, 1980). A follow-up questionnaire was sent out in June 2016.

A peer support group called G7 conducted the third sub-study. Three members of G7 have been part of the steering group of the scaling-up project since its inception, and they have been active as co-researchers. The idea behind the third study is to have persons who have personal experience with homelessness to design a way to research how people perceive their 'home' and housing situation. We also want to know if they have any thoughts on the support that social services provide. One part of the empirical material consists of a questionnaire that the $\mathrm{G} 7$ members have formulated on their own. The other consists of material that has been collected, including photographs of artefacts that the homeless clients think are important and represent what they perceive as being important aspects of a home (cf. Radley, 2005). The photographs will be used in an exhibition and in a printed magazine on the concept of home.

\section{Results}

\section{Scaling up Housing First}

The decision to make Housing First a permanent part of the social housing programme did not mean that all homelessness housing units (e.g. shelters, category housing, training flats, transitional housing) in Helsingborg municipality would be Housing First services. But the evaluation provided recommendations on how the lessons learned from the pilot could be used to develop the social housing programme. One recommendation was to develop a professional relationship building approach that the staff in the social housing programme 
should use. Another recommendation was to develop the possibilities of service user influence within the social housing programme, and thereby take advantage of the users' own views and experiences in the development of the programme. A third recommendation was that the rules and control systems that existed within the social housing programme should be normalized, so that they would more resemble the rules and requirements that apply in the community and in the regular housing market.

The first step in the scaling-up process was to gather all the staff from the different housing units for a two-day joint workshop. First, the intended change was revealed, and the evaluation of the Housing First pilot was presented. The lessons learned were recounted by Housing First tenants in collaboration with the authors of this article. The idea was to create a common vision of the scaling-up project (cf. Zeldin et al., 2005). The second step was to give all the staff the same training in Ml (Miller \& Rollnick, 2013). This was done so the homeless clients would recognise a similar approach, whether they stayed at the emergency shelter or lived in a Housing First apartment. A third step consisted of changing the rules at the different sites. The changes were fairly evident at the emergency shelter. They reduced their rules from a couple of pages to a handful. Many of the different housing alternatives previously had zero-tolerance for drug and alcohol use. As a distinctive part of the scaling-up project, the units started to accept a harm reduction approach. Instead of evicting someone from his or her housing because of a relapse into drug addiction or mental illness, homeless clients were able to remain in the housing unit. Housing was no longer related to the individual client's abstinence or if he or she complied with accepting treatment. This marks a significant shift in the logic of the organisations. A fourth step was to increase the collaboration among the various housing alternatives. If they had previously been part of a housing staircase model where the client climbed from step to step in order to ultimately get a rental contract, they were now all reorganised to be part of a 'cluster' of homelessness services. The idea was that individuals should be able to move from the emergency shelter directly to a Housing First apartment. They should also be able to move from a training flat to a transitional housing unit if they, as service users, felt that they wanted more support or felt the need to have staff on site 24/7. The collaborative component was that, when a client was to move from one site to another, staff from the current housing unit would meet with the client and the staff from the residence the client was moving to. The idea was also that the clients could retain contact with the 'old' support workers, if they chose to. The underlying logic of this collaborative 'handover' was to transfer 
the trusting relationship or alliance that had been established in one place to another (cf. Clarke and Stevens, 2008).

\section{Barriers}

The picture that emerges from the empirical material is that there have been several barriers to the scaling-up process. One of the barriers is the everyday routine and how the work is organised. Instead of talking about changing ways to build relationships with clients, a lot of the work is about organising a better work schedule, for example, preparing meals, dealing with staff shortages, and handling the reoccurring threats of violence or other threats from the clients towards the staff (this is more common at the shelter). One participant stated this clearly:

So, my job in recent years have mostly been to call people and try to get together schedules and tweaking and puzzle and turn things inside and out. It's not what should be the thing... (Interview with social worker)

In relation to the ambition of doing 'handovers', some of the staff were hindered from continuing with this collaborative work because they were prohibited from leaving the premises. One of the staff members was required to stay behind, and this new rule made it difficult to leave the housing unit to visit the other housing alternatives. Previously, the staff from one site had sometimes dropped in for a coffee at another site. For some of the housing alternatives, this was no longer an option due to staff shortages. One interviewee stated it as follows:

We must not leave the place, and before we could when we were at the other place [housing unit]. We could there. Then, we could drive out and visit other places in the weekend, when it was a bit calmer, so we drove out and visited other sites. But now, we have been told that we shall be here and then you do that. (Focus group interview with social workers)

This organisational flaw can probably best be understood as an unintended consequence, but nevertheless a barrier to the plans for and practices of the scaling-up project. We have also noted a conflicting interest (or a lower rate of compatibility with Rogers's [2003] terminology), for some of the staff, between previous practices or ways of working (and memories of housing alternatives that no longer exist) and the new way of working. This has been particularly the case for staff who have had experience working in housing alternatives for older clients with both mental health and substance abuse problems. These units have often been organised around a philosophy of care and doing things together in an institutional-like setting. Much of the work in this situation is to provide the client with daily training (cooking, cleaning etc.) and to do different activities with them. One participant stated this: 
And then we worked much more with social care than we do now. And the meaning is, of course, also that there are not supposed to be as much social care anymore, but, somehow, I think it is needed - a little anyway. Because, for me, it's important that they, for example, can get some food sometimes. (Focus group interview with social workers).

\section{Drivers}

Both in the interviews and focus groups, themes emerged that represent drivers. Most of the interviewed staff felt that the introduction of the Housing First approach can have a positive impact on them and their clients. They said that it is better and more rewarding to work utilizing the Housing First approach, even though it is more difficult because of the organisational constraints. This was expressed by one participant:

It is not always easy. It depends on where you work, but we have the way of thinking here in any case. We want them to go on from here to an apartment of their own, to independent lives, so we try. (Focus group interview with social workers)

Statements such as 'I have just felt that why have we not done like this before? It feels so obvious...'6 from the social workers show their readiness for taking on the new approach, but it is easier to do that when the clients have their own apartment. This view was often presented by the staff that work with Housing First. They said that it is more worthwhile for the social workers to work with the Housing First approach since they get so much back from their clients, both in the way they as individuals find stability in life, but also in the interaction between the social worker and the client. When you can establish a trusting relationship, the potential for change emerges:

By creating relationships, it makes it possible for them to actually dare to say if they have had a relapse. It gives no such consequences as they get kicked out of their accommodation. They can get help instead. (Interview with social worker)

\section{Institutional Change}

In a way, the scaling-up case can be seen as an institutional change in the way homelessness work is organised. This transformation in the way of working has components of all five types of institutional change that Streeck \& Thelen (2005, p. 31) present. First, the scaling-up project can be seen as a form of displacement. The diffusion of Housing First and the adoption of the model by local change agents (institutional entrepreneurs) results in the questioning of

\footnotetext{
${ }^{6}$ Interview with social worker.
} 
the taken-for-granted way of working. Housing First represents another form of logic, which leads to an environment where contradictory logics exist in the same organisation. It is important to note that the time was right for change. In previous research, social workers had expressed an openness to new ways of working since they could see the downside with the existing staircase model (Knutagård, 2009). With Rogers's (2003) terminology, the Housing First approach has the attribute of a relative advantage - Housing First is seen as a better way of working than the staircase model. The compatibility with the values and needs of the social housing programme in Helsingborg is also high, but not equally high in the surrounding organisational field. Moreover, the harm reduction approach can often be more easily adopted by social workers than landlords.

The second type of institutional change is layering. The layering process seems to be connected to those housing alternatives that are less compatible with the new approach. If the organisational constraints are stronger, a layering process might help to change the way of working, but in our estimation, it might be a more difficult transition. The third type is drift, which I also connected to the complex process of both sticking to the core principles at the same time as scaling up the model. In many cases, this leads to 'programme drift', where loyalty to the original model is altered (cf. Padgett et al., 2016; Salveron et al., 2006). Drift can also be seen when the staff expresses an adoption of the new approach, but everyday routine supports the old approach. The opposite is also possible: the organisation keeps the same rules as previously, but the staff does not follow them and institutional drift occurs. In our case, one paradox emerged. Before the introduction of Housing First, homeless clients were often defined as not 'housing ready', and therefore needed another intervention prior to getting an independent apartment in the ordinary housing market (Knutagård, 2009). The logic was that you first had to 'learn how to live' before you could advance to the next step (Sahlin, 2005). Homeless clients who came from a night shelter were considered far from being ready for their own apartment. They had to live collectively, the reasoning went, in some sort of category housing or transitional housing before they could even be considered for a training flat. After the introduction of the Housing First approach, we then heard social workers say that Housing First is for the clients with the most needs. Housing First is for those who have tried everything else but failed, they said. Even though this is not an overall discursive shift, the cases that we have identified so far indicate a reformulation of the situation in order to make it fit with the existing organisational cluster, which can legitimate the sorting of clients into different types of housing. Now, clients that are 'housing ready' have to stay in housing 
alternatives with more rules. In other words, the situation is the total opposite of how homeless people's 'readiness' for an independent apartment is explained. Theoretically, it would have been easier if Housing First represented most of the housing alternatives in the city, but as shown in Table 1, the Housing First apartments represent only $8.5 \%$ of the entire social housing stock.

The fourth type is conversion. This mode of change is visible in the manager's ambition to change the social housing programme. Since it is not possible to actually scale up the number of Housing First apartments or the mobile support teams which are connected to the Housing First service, the existing housing alternatives are being adapted in order to fit the Housing First approach. This can be seen as pragmatic when some institutional structures are too difficult to change. The final mode of change is exhaustion, which consists of a rather gradual breakdown. This type of change is the least visible one in the social housing programme, but the most obvious one in the Housing First service itself. There, it is impossible to legitimate the 'old' way of working when the results show that the new approach gets people housed - clients who were previously defined as hopeless cases. When a microcosmos, such as the scaling-up project in Helsingborg, is subjected to all these types of transformative change at the same time, conflicting logics are then guaranteed to exist, representing a tricky barrier to overcome.

\section{Discussion}

Change takes time, but the scaling-up process has also been affected by changes in the broader context. Context is important in all matters, but especially important in public service organizations (Hartley, 2005). At the same time that the whole process of the scaling-up project started, 'the House' was closed down in 2014. The House was run by a non-governmental organization (NGO) and had begun as a place where homeless people could go and get some food. It was located in one of the industrial areas of the city. From the time the House started its operations, it also accepted homeless people for overnight stays. It transitioned into an emergency shelter with support from the city but was still run by the NGO. When the city decided to scale-up Housing First, they also stopped funding the House, since they did not want that type of housing for homeless people. A consequence of closing the House was that the social services quickly had to find different housing alternatives for those who lived there. This exerted pressure on the existing housing units and a placement process that was not optimal. In 2016, two newly-built housing complexes were offered to the social housing programme. They consisted of 48 new apartments. 
At approximately the same time, 30 contracts for training flats in a different area of the municipality had expired. Thus, the manager of the social housing programme could not refuse the offer. The consequence was that the two complexes with the independent apartments were then offered to two different groups. One was for people with addiction with a zero-tolerance of substance or alcohol use. The other was for clients with mental health problems where a harm reduction approach was to be used - very contradictory philosophies.

Other contextual factors have been the difficult situation of EU migrants and, in the fall of 2015, the humanitarian crisis of refugees from wars in countries such as Syria, Iraq and Afghanistan. However, there is no evidence that the humanitarian crisis has immediately affected the housing market or the homelessness services. New legislation passed in 2016 had an impact on the housing market, since it stipulated that the municipalities had to house the refugees that were placed in the municipality. During the spring of 2016, a new homelessness count was calculated in Helsingborg. The statistics showed an increase in homelessness, which was disturbing considering all the efforts that had been made to find new housing. The count did show, however, that of the 72 acute homeless people (20 sleeping rough), 53 were 'new' homeless persons who had not been part of the previous year's count. In comparison with 2015, there were 9 more homeless people, but 50 persons fewer than in the 2014 count. Thus, in a way, it is complicated to connect the homelessness figures with the scaling-up project. Yet, the impact of these contextual factors is important to analyse, since we can see that they interfere with the implementation of the Housing First programme and, thus, are factors that indirectly or directly affect the shaping of the social innovation. Equally important are the unintended consequences of the implementation of a social innovation such as Housing First. The results of the Housing First pilot led to changes in the general social housing programme: taking away extensive rules in transitional housing and changing the paths possible for homeless clients to take. The actual impact of the social innovation might be on a different level even though it started off as a pilot, it might also have an effect on a structural level.

\section{Conclusion}

The aim of this article is to analyse the drivers that facilitate and the barriers that hinder the scaling up of Housing First pilots. We ask if it is possible to incorporate lessons learned from the Housing First pilot into the existing system 
of homelessness services. In other words: Is it possible to put new wine into old bottles?

In a way, the case of scaling up of Housing First in Helsingborg shows how an innovation that is tested in a local welfare system can produce great results and how policymakers can learn from those results and try to implement the innovation to scale up the method.

Leadership is essential for the scaling-up process. One of the core tasks for the leaders is to emphasize the importance of staff involvement and to make the change process transparent. Staff involvement should be initiated as early as possible to avoid creating the perception of this being a top-down process (cf. Essén \& Lindblad, 2013; Sievanen, et al., 2011). Looking back at the different interventions made, there are some aspects of staff involvement that could have been improved and, thus, would have been positive for the scaling-up process. The two initial staff days in the rural area of Margretetorp (a small town on the west coast in southern Sweden), when the project was launched, were important and gave the staff a sense of belonging with other social workers in the social housing programme. They also felt that they were all part of the change. However, the positive atmosphere and feelings of participation and engagement could probably have been more easily sustained if they would have had a few regular peer-to-peer meetings among the different sites (cf. Talukder \& Quazi, 2011). This was one of the suggestions by the researchers at the start of the project, but it was not implemented. In the follow-up interviews and focus groups, the desire to connect and repeat the vision and goals (the 'innovation narrative') of the scaling-up project were expressed (Barnett et al., 2011).

It is interesting to note that a large part of the staff has been positive about the Housing First concept from the start (both in the interviews and in the first survey). Few have been averse to Housing First. To shift the mindset of frontline staff may not be the biggest challenge. Instead, the greatest resistance lies in the structures that maintain and surround the social housing programme, which means that the structure reproduces a mindset that contributes to discrimination against homeless people. Examples are the difficulty of getting apartments for the social housing programme, the policy under which income support is not considered as a steady income and therefore excludes the recipients as tenants in the ordinary housing market, the difficulties in working with psychiatric services and the great challenge of creating jobs for those who are in the social housing programme. Also, confidence in the Housing First concept is perhaps greater among social workers than among those in power (both politicians and senior officials). 
In many respects, the scaling-up project has been successful. It is somewhat surprising that it so quickly yielded positive and tangible results, both in terms of the reduction of evictions in the social housing programme, but also in how both clients and staff experience and describe the change. One explanation is, of course, that the management has been a driving force and believe in the idea, but just as important (perhaps most importantly), the success lies in that the staff has been supportive of and believed in the Housing First approach. If the staff had been dominated by people who were negative towards the approach and wanted to maintain the treatment first philosophy, we would probably not have seen the changes that we can identify today.

However, there is a real risk associated with the scaling-up project. If housing retention rate is seen as a positive outcome in ordinary apartments, a high 'housing retention' rate is not as positive if the client resides in an emergency shelter. Another risk is the renaming of housing units. Even though they operate under a totally different philosophy, they are renamed as Housing First services. This is not something that we have seen so far in Helsingborg. A greater risk for the city of Helsingborg and other municipalities is that Housing First programmes that are used on a small scale can contribute to the legitimization of maintaining the system of training flats and other forms of housing alternatives and indirectly hinder the scaling-up of the Housing First programme. Municipalities can say that they are working with a Housing First approach at the same time as new training apartments that require abstinence are developed.

Even though the scaling-up project can be seen as successful in such a short time, it still shows limited impact on the overall housing policy in the city of Helsingborg. But, Housing First in Helsingborg cannot be seen as a temporary fad. The Housing First pilot started in 2010, and there is very little evidence that its approach will lose ground due to organisational fatigue. The local champions are important change agents, but they are very much dependent on the inspiration of other key actors in other local contexts and at different levels (Brandsen et al., 2016b; Johnson, 2010). Two areas for future research would be, first, to identify key change agents within organizational settings, the intrapreneurs or the institutional entrepreneurs. These actors could, under the right conditions, help the scaling-up process - if they are given enough support and a mandate. It would be especially interesting to study what conditions are necessary for involving service users. Second, it would be essential to analyse other examples of scaling-up processes and to see the long-term effects of the process on a structural level over time. What do organizations need to do in 
order to give room to something new at the same time as the innovation is still perceived as compatible to the organization's core values, needs and previous experiences.

\section{References}

Arnold, K. R. (2004). Homelessness, citizenship, and identity: The uncanniness of late modernity. Albany: State University of New York Press.

Barnett, J., Vasileiou, K., Djemil, F., Brooks, L., \& Young, T. (2011). Understanding innovators' experiences of barriers and facilitators in implementation and diffusion of healthcare service innovations: A qualitative study. BMC Health Services Research, 11, 342-342. https://doi.org/10.1186/1472-6963-11-342

Brandsen, T., Evers, A., Cattacin, S., \& Zimmer, A. (2016a). Social innovation: A sympathetic and critical interpretation. In: T. Brandsen, A. Evers, S. Cattacin, \& A. Zimmer (Eds.), Social innovations in the urban context. Nonprofit and Civil Society Studies. Springer International Publishing. https://doi.org/10.1007/978-3319-21551-8_1

Brandsen, T., Evers, A., Cattacin, S., \& Zimmer, A. Brandsen, (2016b). The good, the bad and the ugly in social innovation. In: T. Brandsen, A. Evers, S. Cattacin, \& A. Zimmer (Eds.), Social Innovations in the urban context. Nonprofit and Civil Society Studies. Springer International Publishing. https://doi.org/10.1007/978-3319-21551-8_25

Clarke, S., \& Stevens, E. (2008). Sustainable leadership in small rural schools: Selected Australian vignettes. Journal of Educational Change 10(4), 277-293. https://doi.org/10.1007/s10833-008-9076-8

Davis, M. H. (1980). A multidimensional approach to individual differences in empathy. JSAS Catalog of Selected Documents in Psychology, 10, 85.

Dupuis, A., \& Thorns, D. C. (1998). Home, home ownership, and the search for ontological security. The Sociological Review, 46(1), 24-47. https://doi.org/10.1111/1467-954x.00088

Essén, A., \& Lindblad, S. (2013). Innovation as emergence in healthcare: Unpacking change from within. Social Science \& Medicine, 93, 203-211. https://doi.org/10.1016/i.socscimed.2012.08.035

Felton, B. J. (2003). Innovation and implementation in mental health services for homeless adults: A case study. Community Mental Health Journal, 39(4), 309322.

George, A. L., \& Bennett, A. (2005). Case studies and theory development in the social sciences. Cambridge, MA: MIT Press.

Godin, B. (2012). Social innovation: Utopias of innovation from c.1830 to the present. Project on the intellectual history of innovation. Working Paper No. 11. Retrieved from http://www.csiic.ca/PDF/Sociallnnovation_2012.pdf

Greenhalgh, T., Macfarlane F., Barton-Sweeney, C., \& Woodard, F. (2012). If we build it, will it stay? A case study of the sustainability of whole-system change in London. Milbank Quarterly, 90(3), 516-547. https://doi.org/10.1111/j.1468$\underline{0009.2012 .00673 . x}$

Greenhalgh, T., Robert, G., Macfarlane, F., Bate, P., \& Kyriakidou, O. (2004). Diffusion of innovations in service organizations: Systematic review and recommendations. 
Milbank Quarterly, 82(4), 581-629. $\quad$ https://doi.org/10.1111/j.0887378x.2004.00325.x

Hardy, C., \& Maguire, S. (2008) Institutional entrepreneurship. In: R. Greenwood (Ed.), The SAGE handbook of organizational institutionalism. London: SAGE. https://doi.org/10.4135/9781849200387.n8

Hartley, J. (2005). Innovation in governance and public services: Past and present Public Money \& Management, 25(1), 27-34.

Iriss (2016). Innovation and improvement. Retrieved from http://www.iriss.org.uk/about/innovation

Johnson, S. (2010). Where good ideas come from: The natural history of innovation. New York: Riverhead Books.

Kazepov, Y. (2010). Rescaling social policies towards multilevel governance in Europe: Some reflections on processes at stake and actors involved. In: Y. Kazepov (Ed.), Rescaling social policies: Towards multilevel governance in Europe. Farnham: Ashgate. https://doi.org/10.4324/9781315244433-1

Klein, J-L. (2013). Introduction: Social innovation at the crossroads between science, economy and society. In: F. Moulaert, D. MacCallum, A. Mehmood, \& A Hamdouch (Eds.), The international handbook on social innovation: Collective action, social learning and transdisciplinary research. Cheltenham: Edward Elgar. https://doi.org/10.4337/9781849809993

Knutagård, M. (2009). Skälens fångar. Hemlöshetsarbetets organisering, kategoriseringar och förklaringar. [Prisoners of reasons: organization, categorizations and explanations of work with the homeless]. Dissertation. Malmö: Égalité.

Knutagård, M. (2015). Bostad först som strategi eller strategisk strimma [Housing First as Strategy or Strategic Streak], Alkohol \& Narkotika (4), 12-15.

Knutagård, M., \& Kristiansen, K. (2013). Not by the Book: The Emergence and Translation of Housing First in Sweden. European Journal of Homelessness, 7(1), 93-115.

Knutagård, M. \& Kristiansen, K. (2016). Scaling Up Housing First Pilots - Drivers and Barriers. Paper presented at the Third ISA Forum of Sociology, The Futures We Want: Global Sociology and the Struggles for a Better World, Vienna, Austria, July 10-14, 2016.

Kristiansen, A. (2013). Utvärdering av Bostad först-projektet i Helsingborg. Slutrapport. [Evaluation of the Housing First project in Helsingborg. Final report]. Helsingborg: Socialförvaltningen, Helsingborgs stad.

Kristiansen, A., \& Espmarker, A. (2012). Sen är det ju mycket det här att man får vara ärlig också och det är man ju inte van vid... Bostad först ur de boendes perspektiv. [Then it is a lot of this that you can be honest too, and you are not used to that ... Housing first from the perspective of the residents]. Lund: Socialhögskolan, Lunds universitet, Working paper serien 2012:4. https://doi.org/10.2307/40144653

Lind, H., \& Lundström, S. (2007). Bostäder på marknadens villkor [Housing on the conditions of the market]. Stockholm: SNS.

Lindbom, A. (2001). Dismantling Swedish housing policy, Governance, 14(4), 503-526. https://doi.org/10.1111/0952-1895.00171

Martinelli, F. (2012). Social innovation or social exclusion? Innovating social services in the context of a retrenching welfare state. In: H. W. Franz, J. Hochgerner, \& J. Howaldt (Eds.), Challenge social innovation: Potentials for business, social 
entrepreneurship, welfare and civil society. Berlin and Heidelberg: Springer Berlin Heidelberg. https://doi.org/10.1007/978-3-642-32879-4_11

Mazzucato, M. (2013). The entrepreneurial state: Debunking public vs. private sector myths. London: Anthem Press. https://doi.org/10.4337/roke.2015.01.10

Milat, A. J., King, L., Bauman, A. E., \& Redman, S. (2012). The concept of scalability: Increasing the scale and potential adoption of health promotion interventions into policy and practice. Health Promotion International, 28(3), 285-298. https://doi.org/10.1093/heapro/dar097

Miller, W. R., \& Rollnick, S. (2013). Motivational interviewing: Helping people change (3rd ed.). New York: Guilford Press.

Moulaert, F., MacCallum, D., \& Hillier, J. (2013). Social innovation: Intuition, precept concept, theory and practice. In: F. Moulaert, D. MacCallum, A. Mehmood, \& A Hamdouch (Eds.), The International Handbook on Social Innovation: Collective Action, Social Learning and Transdisciplinary Research. Cheltenham: Edward Elgar. https://doi.org/10.4337/9781849809993.00011

NBHW (2017). Hemlöshet 2017: omfattning och karaktär. [Homelessness 2017: Extent and Character]. Stockholm: National Board of Health and Welfare.

Padgett, D. K. (2007) There's no place like (a) home: Ontological security among persons with serious mental illness in the United States. Social Science \& Medicine, 64, 1925-1936. https://doi.org/10.1016/j.socscimed.2007.02.011

Padgett, D. K., Henwood, B., \& Tsemberis, S. (2016). Housing first: Ending homelessness, transforming systems, and changing lives. New York: Oxford Press. https://doi.org/10.1093/acprof:oso/9780199989805.001.0001

Pleace, N. (2016). Housing First Guide Europe. Retrieved from http://housingfirstguide.eu/website/

Pleace, N., Culhane, D., Granfelt, R., \& Knutagård, M. (2015). The Finnish Homelessness Strategy - An International Review. REPORTS OF THE MINISTRY OF THE ENVIRONMENT 3en | 2015.

Radley, A., Hodgetts, D., \& Cullen, A. (2005). Visualizing homelessness: A study in photography and estrangement. Journal of Community \& Applied Social Psychology, 15(4), 273-295. https://doi.org/10.1002/casp.825

Rogers, E. M. (2003). Diffusion of innovations (5th ed.). New York: Free Press.

Rønning, R., Knutagård, M., Heule, C. \& Swärd, H. (2013). Innovationer i välfärden möjligheter och begränsningar. [Innovations in welfare - possibilities and limitations]. Stockholm: Liber.

Rønning, R., \& Knutagård, M. (2015). Innovation in Social Welfare and Human Services. New York: Routledge.

Sahlin, I. (2005). The staircase of transition. Survival through failure. Innovation, 18(2), 115-135.

Sahlin, I. (2015). Searching for a homeless strategy in Sweden. European Journal of Homelessness, 9(2), 161-186.

Salveron, M., Arney, F., \& Scott, D. (2006). Sowing the seeds of innovation: Ideas for child and family services. Family Matters, 73, 38-45.

Sievanen, L., Leslie, H. M., Wondolleck, J. M., Yaffee, S. L., McLeod, K. L., \& Campbell, L. M. (2011). Linking top-down and bottom-up processes through the new U.S. National Ocean Policy. Conservation Letters, 4(4), 298-303. https://doi.org/10.1111/j.1755-263x.2011.00178.x 
Streeck, W., \& Thelen, K. A. (2005). Introduction: Institutional change in advanced political economies. In: W. Streeck, \& K. A. Thelen (Eds.), Beyond continuity: Institutional change in advanced political economies. New York: Oxford University Press. https://doi.org/10.1177/09589287070170020602

Talukder, M., \& A. Quazi (2011). The impact of social influence on individuals' adoption of innovation. Journal of Organizational Computing and Electronic Commerce, 21(2), 111-135. https://doi.org/10.1080/10919392.2011.564483

Tsemberis, S. (2015) Housing First: The pathways model to end homelessness for people with mental health and substance use disorders. Revised and updated for the DSM-5 edition. Center City, MN: Hazelden.

What Works Scotland Evidence Review (2015). Scaling-up innovations. Retrieved from http://whatworksscotland.ac.uk/wp-content/uploads/2015/06/WWS-EBevidence-review-Scaling-Up-Innovations-June-2015.pdf https://doi.org/10.1787/9789264229488-2-en

Wibeck, V. (2010). Fokusgrupper: om fokuserade gruppintervjuer som undersökningsmetod. [Focus groups: on focused group interviews as a research method] 2., uppdaterade och utök. uppl. Lund: Studentlitteratur.

Zeldin, S., Camino, L., \& Mook, C. (2005). The adoption of innovation in youth organizations: Creating the conditions for youth-adult partnerships. Journal of Community Psychology, 33(1), 121-135. https://doi.org/10.1002/jcop.20044 